\section{Quality Attributes Limiting Snap Bean (Phaseolus vulgaris L.) Postharvest Life at Chilling and Non-chilling Temperatures}

\author{
Emilie Proulx \\ University Laval-Faculté des Sciences de l'Agriculture et de l'Alimentation, \\ Québec, Canada, G1K 7P4
}

Yavuz Yagiz and M. Cecilia N. Nunes ${ }^{1}$

Food Science and Human Nutrition Department, University of Florida, IFAS, Gainesville, FL 32611-0370

\section{Jean-Pierre Emond Agricultural and Biological Engineering Department, University of Florida, IFAS, Gainesville, FL 32611-0570}

Additional index words. storage, chilling injury, fruit quality, fruit composition

\begin{abstract}
Opus' and 'Leon' snap beans were harvested, hydrocooled, held for 2 to 7 days at five temperatures and evaluated for quality attributes. The objectives of this work were to obtain quality curves at chilling and non-chilling temperatures, identify for each temperature which quality attributes limit snap beans marketability, and determine the remaining compositional value at the point the snap beans had reached the minimum acceptable quality for sale. Results from this study showed that temperature had a significant effect on the shelf life and overall quality of snap bean. Snap beans stored at temperatures higher than $10^{\circ} \mathrm{C}$ were less green, softer and more shriveled, had higher weight loss, and lower acidity, soluble solids, ascorbic acid, and chlorophylls contents than those stored at lower temperatures. When stored at 1,5 , and $10{ }^{\circ} \mathrm{C}$, 'Leon' snap beans developed chilling injury (CI), whereas no visual symptoms were noticeable in 'Opus' snap beans. Although CI might have indirectly affected the quality of 'Leon' snap beans, it was not considered a sensory quality-limiting factor. Overall, weight loss was the first non-sensory quality attribute to reach the limit of acceptability, whereas firmness was the first sensory quality attribute, followed by color, to reach the limit of acceptability and therefore limited the shelf life of 'Opus' and 'Leon' snap beans cultivars. As a result of excessive water loss and accelerated softening, shelf life of both snap bean cultivars was relatively short, ranging from 1 to 3.5 days, depending on the temperature and cultivar. Furthermore, the compositional value was considerably reduced at the point of poor sensory quality. The high weight loss obtained for beans stored at all temperatures suggests that the use of a film wrap may help create a high relative humidity and therefore reduce water loss, maintain better overall quality, and extend the shelf life of snap beans. Overall, maximum shelf life and best quality were obtained when 'Opus' and 'Leon' snap beans were stored at $10^{\circ} \mathrm{C}$.
\end{abstract}

The continuous development of improved snap bean cultivars throughout the years has provided germplasm with wide variety of colors, textures, shapes, and sizes to meet the growing conditions and taste preferences of consumers from many different regions (Orzolek et al., 2000). In 2001, the collection of the Food and Agriculture Organization included 26,500 Phaseolus vulgaris entries,

\footnotetext{
Received for publication 7 May 2010. Accepted for publication 11 June 2010

We express our gratitude to Dr. Jeffrey K. Brecht of the Horticultural Sciences Department at the University of Florida for his helpful and valuable comments and suggestions and for the use of his laboratory.

${ }^{1}$ To whom reprint requests should be addressed; e-mail cnunes@ifas.ufl.edu.
}

reflecting a large genetic diversity (CIAT, 2001). Such diversity can explain the wide variation in shelf life, resistance to chilling temperatures as well as variability in physical and chemical attributes. Generalization of sensory and compositional attributes among snap bean cultivars is difficult. Quality differentiation among individual fruits and vegetables by consumers is based primarily on appearance (Zind, 1989). In snap beans, color is an important feature, which changes from a desirable bright green to an objectionable yellowish color (Trail et al., 1992). Textural attributes and loss of chlorophylls are also excellent indices of quality because they parallel color changes, loss of ascorbic acid, and offflavor development (Cain et al., 1953; Martinez et al., 1995).

Quality at harvest and environmental conditions, particularly temperature, during the postharvest period greatly affect the shelf life and quality of snap beans. It is well recognized that good temperature management is the simplest way to maintain a high-quality appearance as well as to delay losses in the nutritional value of fruits and vegetables in general (Nunes, 2008a; Nunes and Emond, 2002). As a result of their high respiration rate and sensitivity to chilling temperatures, snap beans are very perishable (Costa et al., 1994). Therefore, for a maximum shelf life of 8 to $12 \mathrm{~d}$, recommended storage temperatures range from 5 to $7.5{ }^{\circ} \mathrm{C}$ with $95 \%$ to $100 \%$ relative humidity (Cantwell and Suslow, 2010; Hardenburg et al., 1986). When stored at temperatures above the recommended, snap beans will show discoloration, yellowing, loss of firmness, and a leathery appearance, whereas when stored at temperatures below the recommended, the pods will develop chilling injury (CI) symptoms such surface pitting, diagonal brown streaks, dull appearance, and breakdown from microorganisms after transfer to warm temperature (Nunes, 2008a; Watada and Morris, 1966b). However, sensitivity to chilling temperatures seems to be cultivar-dependent (Watada and Morris, 1966a). In addition to good temperature management, minimizing the time between harvest and sale prevents decrease in chlorophylls and vitamin C contents, increased weight loss resulting from loss of moisture, and reduced crispness (Sistrunk et al., 1989).

Much of the research work done on snap beans has been directed to the processing industry (Ferreira et al., 2006; Freeman and Sistrunk, 1978; Gould et al., 1951; Kahn and McGlynn, 2009; Woodruff et al., 1962) with a few recent studies on fresh produce (Cano et al., 1998; Costa et al., 1994; Kahn and McGlynn, 2009; Martinez et al., 1995; Nunes et al., 2001). No data were however found in the literature regarding quality curves for snap beans stored at various temperatures. In fact, the few previous published studies report the optimum storage temperature for snap beans (Monreal et al., 1999; Trail et al., 1992) or the response to storage at chilling temperatures (Abou Aziz et al., 1976; Gorini et al., 1974; Watada and Morris, 1966a, 1966b) rather than changes in quality that develop over time and over a wide range of temperatures. In addition, previous studies have shown that the quality attributes that limit shelf life may vary depending on the commodity and storage temperature and therefore one single attribute should not be used to determine the end of the shelf life of a particular fruit or vegetable (Nunes et al., 2004, 2007; Proulx et al., 2005). Yet again, no information was found regarding the most important sensory quality attributes that determine the limits of marketability for snap beans stored at various temperatures. Finally, although the sensory quality of a specific commodity may still be considered acceptable for sale or consumption, the remaining compositional value might have been already significantly reduced.

The objectives of this work were to: 1) create quality curves for snap beans stored at 
chilling and non-chilling temperatures; 2) identify which sensory quality attribute limits the shelf life and marketability of snap beans when stored at chilling and non-chilling temperatures; and 3 ) evaluate the remaining compositional value at the point the snap beans had reached the minimum acceptable quality for sale.

\section{Materials and Methods}

Plant material and storage conditions. Snap beans (Phaseolus vulgaris L.) cvs. Opus and Leon were harvested at commercial maturity (i.e., bright green, tender fleshy and with small green immature seeds) from a commercial field in Homestead, FL. A total of two harvests (experiments) were conducted during the winter season (i.e., February to March). Snap beans were removed from the field with minimal delay after harvest, commercially hydrocooled, and transported to the laboratory in Gainesville, $\mathrm{FL}$, within $\approx 6 \mathrm{~h}$. Beans were then sorted by size, color, and freedom of defects. 'Opus' snap bean pod weight averaged $6.0 \mathrm{~g}$, whereas 'Leon' snap bean pod weight averaged $10.0 \mathrm{~g}$. A total of 2160 snap bean pods per cultivar were selected for uniformity of color and freedom from defects, weighed, and carefully distributed by 144 polyethylene terephthalate vented clamshells (capacity $\approx 453 \mathrm{~g}$ ) (Pactiv Corporation North America, Lake Forest, IL) containing 15 snap bean pods each. To create a relative humidity $(\mathrm{RH})$, without however modifying the atmosphere around the pods, the clamshells were placed inside open large opaque plastic bags (Glad Products Company, Amherst, VA Amherst, VA AmherstVA,). Clamshells containing the selected snap beans were then stored at $0.5 \pm 0.5{ }^{\circ} \mathrm{C}$ and $90.0 \pm 3.5 \% \mathrm{RH}$, $5.0 \pm 0.5^{\circ} \mathrm{C}$ and $93.2 \pm 3.5 \% \mathrm{RH}, 10.0 \pm 0.5$ ${ }^{\circ} \mathrm{C}$ were $94.0 \pm 3.5 \% \mathrm{RH}, 15 \pm 0.5{ }^{\circ} \mathrm{C}$ and $92.0 \pm 3.5 \% \mathrm{RH}$, and $20.0 \pm 0.5^{\circ} \mathrm{C}$ and $93.0 \pm$ $3.5 \%$ RH. For ease of interpretation, temperatures were rounded to $1,5,10,15$, and $20^{\circ} \mathrm{C}$.

Temperature and relative humidity monitoring. The temperature inside the plastic bags containing the snap bean trays were monitored throughout storage using Stow Away® XTI02 temperature loggers ( -5 to $+37{ }^{\circ} \mathrm{C}$ ) (Onset Computer Corporation, Pocasset, MA). RH was monitored with Stow Away® RH loggers (10\% to 95\% RH) (Onset Computer Corporation).

Experimental setup. Three clamshells containing 15 snap bean pods each (a total of 45 pods) were used for initial sensory quality evaluations (color, browning, firmness, shriveling, and pitting) and immediately frozen to be later used for chemical compositional analysis $(\mathrm{pH}$, titratable acidity, and soluble solids, ascorbic acid, and chlorophylls contents). Fifteen clamshells containing 15 snap bean pods each (a total of 225 pods) were distributed among the five temperature-controlled rooms and reused daily for non-destructive quality evaluations (sensory quality and weight). That is, each day the same three clamshells were removed from their respective temperature to a temperature-controlled room $\left(\approx 20^{\circ} \mathrm{C}\right)$ for $\approx 30$ min, sensory quality evaluated and weight measured, and then returned to their respective temperature. Likewise, for daily destructive quality evaluations, 105 clamshells containing 15 snap bean pods each (a total of 1575 pods) were distributed among the five temperature-controlled rooms. However, each day, three of these clamshells were removed from their respective temperature and immediately placed inside a $-80{ }^{\circ} \mathrm{C}$ freezer to be later used for chemical compositional analysis. Finally, to evaluate the effect of storage at 1,5 , and $10{ }^{\circ} \mathrm{C}$ on the development of CI symptoms, 21 clamshells containing 15 snap bean pods each (a total of 315 pods) were distributed among the chilling temperatures (a total of seven clamshells per temperature). Each day, one clamshell was removed from each of the chilling temperatures, transferred to $20{ }^{\circ} \mathrm{C}$ for 1 additional day, and then CI symptoms (i.e., pitting, rusty spots, and discoloration) were evaluated. In summary, 24 clamshells containing 15 pods each were stored at 15 and $20{ }^{\circ} \mathrm{C}$ (three for non-destructive quality evaluations and 21 for destructive quality evaluations) and 31 clamshells containing 15 pods each were stored at 1,5 , and $10{ }^{\circ} \mathrm{C}$ (three for non-destructive quality evaluations, 21 for destructive quality evaluations, and 7 for $\mathrm{CI}$ evaluation). The total amount of clamshells/ snap bean pods was calculated based on a 7-d storage period; however, storage was ended when the quality of the snap beans was considered unacceptable for sale or consumption. Therefore, storage times varied from 2 to $7 \mathrm{~d}$, depending on the cultivar and storage temperature (see "Results and Discussion" section).

Instrumental color. Surface color measurements were taken on each individual bean from clamshells designated for sensory evaluation at $5 \mathrm{~cm}$ from the bean stem end with a handheld tristimulus reflectance colorimeter (Model CR-300; Minolta Co., Ltd., Osaka, Japan) equipped with a glass lightprotection tube with an 8-mm aperture (CRA33a; Minolta Co., Ltd.) using standard illuminant D65. Color was recorded using the CIE-L*a*b* uniform color space (CIELaboratory), $\mathrm{L}^{*}$ (lightness), a* (redness), and $b^{*}$ (yellowness) values. Numerical values of $\mathrm{a}^{*}$ and $\mathrm{b}^{*}$ were converted into hue angle and chroma using the Minolta Color Management Software (1996-1999 CyberSoft SpectraMatch/QC software Version 3.3; CyberChrome, Inc., Stone Ridge, NY).

Sensory quality. Sensory quality evaluation of snap beans was performed daily during a 2- to 7-d storage period, depending on the cultivars and storage temperature, always by the same trained person. Surface color, browning severity, shriveling, and CI (i.e., pitting, rusty spots, and discoloration) were determined subjectively using a 1 to 5 visual rating scale, and firmness was determined subjectively based on the whole snap beans resistance to slight applied finger pressure and recorded using a 1 to 5 tactile rating (Table 1). A score of 3 was considered to be the limit of acceptability for sale.

To compare weight loss and sensory quality attributes, weight loss percentages were converted into a 1 to 5 rating scale. The maximum acceptable weight loss (before considered unmarketable) was set at $5 \%$ (Robinson et al., 1975). Ratings for weight loss were as follows: $1=10.0 \%$ or more

Table 1 . Visual quality scores and descriptors for snap beans.

\begin{tabular}{|c|c|c|c|c|c|}
\hline & \multicolumn{5}{|c|}{ Scores and description } \\
\hline & 1 & 2 & $3^{\mathrm{z}}$ & 4 & 5 \\
\hline$\overline{\text { Color }^{y}}$ & $\begin{array}{l}\text { Extremely dull green } \\
\text { or completely yellow } \\
\text { or brownish }\end{array}$ & $\begin{array}{l}\text { Dull green (yellowing } \\
\text { or brownish spots) }\end{array}$ & Green & Less bright light green & $\begin{array}{l}\text { Extremely bright light } \\
\text { green }\end{array}$ \\
\hline Browning & Extreme browning & Severe browning & Moderate browning & Slight browning & No browning \\
\hline Firmness $^{\mathrm{x}}$ & $\begin{array}{l}\text { Extremely soft on touch, } \\
\text { does not snap }\end{array}$ & $\begin{array}{l}\text { Soft on touch, bents } \\
\text { easily, does not snap }\end{array}$ & $\begin{array}{l}\text { Tender but less firm, } \\
\text { does not snap easily }\end{array}$ & $\begin{array}{l}\text { Tender and firm on } \\
\text { touch, snap easily }\end{array}$ & $\begin{array}{l}\text { Extremely tender and firm, } \\
\text { snaps very easily }\end{array}$ \\
\hline $\mathrm{CI}^{\mathrm{w}}$ & $\begin{array}{l}\text { Severe pitting, large rusty } \\
\text { spots, discoloration of } \\
\text { the entire pod }\end{array}$ & $\begin{array}{l}\text { Moderate pitting, } \\
\text { medium rusty spots, } \\
\text { and discoloration }\end{array}$ & $\begin{array}{l}\text { Slight pitting, small } \\
\text { rusty spots }\end{array}$ & $\begin{array}{l}\text { Trace (small pits or rusty } \\
\text { spots) }\end{array}$ & No abnormality \\
\hline
\end{tabular}

${ }^{\mathrm{z}} \mathrm{Score}$ of 3 was considered to be the minimum acceptable quality before snap beans become unmarketable.

${ }^{\mathrm{y}}$ Martinez et al., 1995.

${ }^{\times}$Quintana and Paull, 1993.

${ }^{\text {w }}$ Chilling injury was evaluated after 1 additional day at $20^{\circ} \mathrm{C}$. 
weight loss, $2=7.5 \%$ weight loss, $3=5.0 \%$ weight loss (maximum acceptable), $4=2.5 \%$ weight loss, $5=0 \%$ weight loss. The following formula was used to convert percentage of weight loss into ratings values: [ $(\%$ weight loss $/ 10 \times 4)+1]$.

Weight loss. Weight loss of each replicate of 15 snap beans was calculated from the initial weight of beans and after each day during a 2- to 7-d storage period depending on cultivar and storage temperature. Concentrations of chemical constituents were expressed in terms of dry weight to show the differences between temperatures that might be obscured by differences in water content. The following formula was used for water loss corrections: [chemical components (fresh weight) $\times 100 \mathrm{~g} / 9.7 \mathrm{~g}$ (snap beans average dry weight) + weight loss during storage $(\mathrm{g})]$. Snap beans dry weight was determined by drying three weighed aliquots of homogenized snap bean tissue at $80^{\circ} \mathrm{C}$ and until weight stabilized.

$\mathrm{pH}$ and titratable acidity. Chopped snap beans (20.0 g per replicate) were mixed with $10.0 \mathrm{~g}$ of distilled water ( $\mathrm{pH} 6.8$ to 7.2 ) and homogenized in laboratory blenders at high speed for $1 \mathrm{~min}$. The homogenates were centrifuged at $800 \mathrm{~g}_{\mathrm{n}}$ for $30 \mathrm{~min}$, filtered through cheesecloth, and the $\mathrm{pH}$ of the juice was determined using a $\mathrm{pH}$ meter (Accumet Model 15; Fisher Scientific, Arvada, CO) that had been previously standardized to $\mathrm{pH} 4$ and $\mathrm{pH} 7$. Aliquots $(6.0 \mathrm{~g})$ of the juice were diluted with $50 \mathrm{~mL}$ distilled water and the titratable acidity determined by titration with $0.1 \mathrm{~N} \mathrm{NaOH}$ to an end point of $\mathrm{pH} 8.1$ with an automatic titrimeter (Titroline 96; SCHOTTGERÄTE GmbH, Germany). The results were converted to percent malic acid, the main organic acid in snap beans (Martinez et al., 1995) using the following formula: $[(\mathrm{mL} \mathrm{NaOH} \times 0.1 \mathrm{~N} \times 0.064 \mathrm{meq} / 6.00 \mathrm{~g}$ of juice) $\times 100]$. Titratable acidity was expressed in terms of dry weight.

Soluble solids content. The soluble solids content (SSC) of the resulting clear juice samples (see previously) was measured with a digital refractometer (Palette PR-101, 0 to $45^{\circ}$ Brix; Atago Co. Ltd., Tokyo, Japan) and was expressed in terms of dry weight.

Total ascorbic acid content. For total ascorbic acid analysis, $5.0 \mathrm{~g}$ of homogenized tissue from each replicate was combined with $50 \mathrm{~mL}$ of a mixture of $6 \%$ metaphosphoric acid and $2 N$ acetic acid. The bean-acid mixtures were centrifuged for $20 \mathrm{~min}$ at $5000 \mathrm{~g}_{\mathrm{n}}$. The analysis was performed by the dinitrophenylhydrazine method of Terada et al. (1978). The concentration of total ascorbic acid was calculated from absorbance measured at $540 \mathrm{~nm}$ using a standard curve. Concentration of ascorbic acid was expressed in terms of dry weight.

Total chlorophyll content. Frozen chopped snap beans $(10.0 \mathrm{~g})$ were homogenized in the dark with $10 \mathrm{~mL}$ of $80 \%$ acetone until the tissue was fine slurry. Acetone $80 \%(5 \mathrm{~mL})$ was used to wash the blade of the homogenizer. The mixture was kept in the dark for $24 \mathrm{~h}$ at $4{ }^{\circ} \mathrm{C}$. The tissue slurry solution was rehomogenized and the blades were washed with $5 \mathrm{~mL}$ of $80 \%$ acetone. The snap beanacetone extracts (total of $20 \mathrm{~mL}$ acetone) were centrifuged at $800 \mathrm{~g}_{\mathrm{n}}$ for $10 \mathrm{~min}$ in a benchtop centrifuge. Absorbency of the clear solution was read at 645 and $663 \mathrm{~nm}$. Concentration of total chlorophylls in $\mathrm{g} \cdot \mathrm{mL}^{-1}$ was calculated according to the Standard Operating Procedures of the EPA-ERT (1994). Chlorophylls content was expressed in terms of dry weight.

Limiting quality factor. For each temperature, a limiting quality factor was established considering the rating value of 3 as the maximum acceptable quality before the fruit becomes unmarketable. More specifically, for each temperature, the factor that limited the product marketability was identified from the quality curves.

Statistical analysis. A completely randomized design was used with a factorial arrangement of five storage temperatures (1, $5,10,15$, and $\left.20{ }^{\circ} \mathrm{C}\right)$, eight evaluation times $(0,1,2,3,4,5,6$, and $7 \mathrm{~d})$, and three replicates of 15 snap beans each applied to two different snap bean cultivars. The Statistical Analysis System computer package (SAS Institute Inc., 1982) was used for the analysis of the data. The data from each cultivar were treated by two-way analysis of variance with storage temperature and storage time as factors. To determine the primary limiting factor(s), the quality attributes for each temperature were compared using the least significant difference at the 5\% significance level. For each cultivar and storage temperature, Pearson's correlation coefficients $(r)$ were calculated between chlorophyll content and visual color scores and between $\mathrm{L}^{*}$, hue, or chroma values. Pearson's correlation coefficients $(r)$ were also calculated between weight loss and color, firmness, shriveling, and CI.

\section{Results and Discussion}

Storage period. The storage period for 'Opus' and 'Leon' snap bean cultivars was ended when the overall quality was considered unacceptable for sale or consumption, that is when the pods were visibly deteriorated or when at least one of the sensory attributes evaluated had attained rating of 2 or lower (poor to very poor) (Figs. 1 and 2). Based on these criteria, the storage periods for 'Opus' snap beans were $7 \mathrm{~d}$ at 1 and $5{ }^{\circ} \mathrm{C}$ and 5,4 , and $3 \mathrm{~d}$ at 10,15 , and $20^{\circ} \mathrm{C}$, respectively. Likewise, storage for 'Leon' snap beans was ended after $5,7,6,3$, and $2 \mathrm{~d}$ at $1,5,10,15$, and $20^{\circ} \mathrm{C}$, respectively.

Instrumental color. Changes in $\mathrm{L}^{*}$, hue angle and chroma values of 'Opus and 'Leon' snap beans during storage at different temperature are shown in Figure 3. At the time of harvest, 'Opus' snap beans were darker (lower L* value) and greener (higher hue value) but with similar vividness (similar chroma values) compared with 'Leon' snap beans. Color of snap beans measured by L*, hue, and chroma did not change much during storage as compared with visual observations
(Figs. 1 and 2). Furthermore, there was no significant difference in $\mathrm{L}^{*}$, hue, and chroma values of snap beans stored at different temperatures. However, by the end of the storage period ( $5 \mathrm{~d})$, pods of 'Leon' snap beans stored at $1{ }^{\circ} \mathrm{C}$ had lower $\mathrm{L}^{*}$ values (darker) compared with those stored at higher temperatures for the same period of time. After $7 \mathrm{~d}$, snap beans stored at $5{ }^{\circ} \mathrm{C}$ were more yellowish (lower hue) than those stored for 2 to $5 \mathrm{~d}$ at higher temperatures. Overall, by the end of the storage period at each respective temperature, color of snap beans was more dull (lower chroma) than at time of harvest, particularly for 'Opus' snap beans.

Although superficial color intensity is dependent on the snap bean cultivar and maturity of the pod at harvest (Mayland and Dean, 1971), increasing the storage time and temperature often results in loss of brightness and greenness and increased yellowing. Trail et al. (1992) also reported that after $8 \mathrm{~d}$, snap beans stored at $10^{\circ} \mathrm{C}$ were lighter (higher $\mathrm{L}^{*}$ ) than pods stored at $5{ }^{\circ} \mathrm{C}$, but after $16 \mathrm{~d}$, lightness of the pods stored at $5{ }^{\circ} \mathrm{C}$ increased significantly compared with days 4 and 8 . After $16 \mathrm{~d}$, hue and chroma of snap beans stored at either 5 or $10{ }^{\circ} \mathrm{C}$ decreased significantly indicating a loss of greenness and brightness of the pods (Trail et al., 1992). In the present study, smaller changes in $\mathrm{L}^{*}$, hue, and chroma values compared with significant changes in the visual color of both snap bean cultivars might have been because instrumental color was measured only in a small area of the pod (at $5 \mathrm{~cm}$ from the bean stem end), whereas, although subjective, visual observations covered the entire pod.

Sensory quality. Color intensity of snap beans pods decreases with physiological maturity (Mayland and Dean, 1971), whereas it is also greatly affected by storage (Abou Aziz et al., 1976; Watada and Morris, 1966b). In this study, visual color of both snap bean cultivars deteriorated during storage, regardless of the temperature, because the pods became less bright green, duller, and more yellow (Figs. 1 and 2). However, color of snap beans stored at 15 and $20{ }^{\circ} \mathrm{C}$ tended to deteriorate faster than that of pods stored at lower temperatures. Abou Aziz et al. (1976) also reported that development of yellowing and overall rate of deterioration of green snap beans was lower at $10{ }^{\circ} \mathrm{C}$ compared with storage at $20^{\circ} \mathrm{C}$. Color of 'Opus' snap beans stored at $1,5,10$, and $15^{\circ} \mathrm{C}$ attained the limit of acceptability after $\approx 2.5 \mathrm{~d}$ of storage (Figs. 1 and 2). However, after day 3, visual evaluations showed that color of 'Opus' beans stored at 10 and $15{ }^{\circ} \mathrm{C}$ deteriorated faster than that stored at 1 or $5{ }^{\circ} \mathrm{C}$. For 'Leon' snap beans, there was a more obvious difference between the color of pods stored at different temperatures. After $\approx 2.5 \mathrm{~d}$, color of snap beans stored at $15{ }^{\circ} \mathrm{C}$ attained the limit of acceptability followed by color of snap beans stored at 5 and $10^{\circ} \mathrm{C}$ that attained the acceptability limit after $\approx 4 \mathrm{~d}$. Color of snap beans stored at 1 and 20 ${ }^{\circ} \mathrm{C}$ never attained the limit of acceptability during the storage period evaluated ( 5 and $2 \mathrm{~d}$, respectively) because other sensory attributes, 


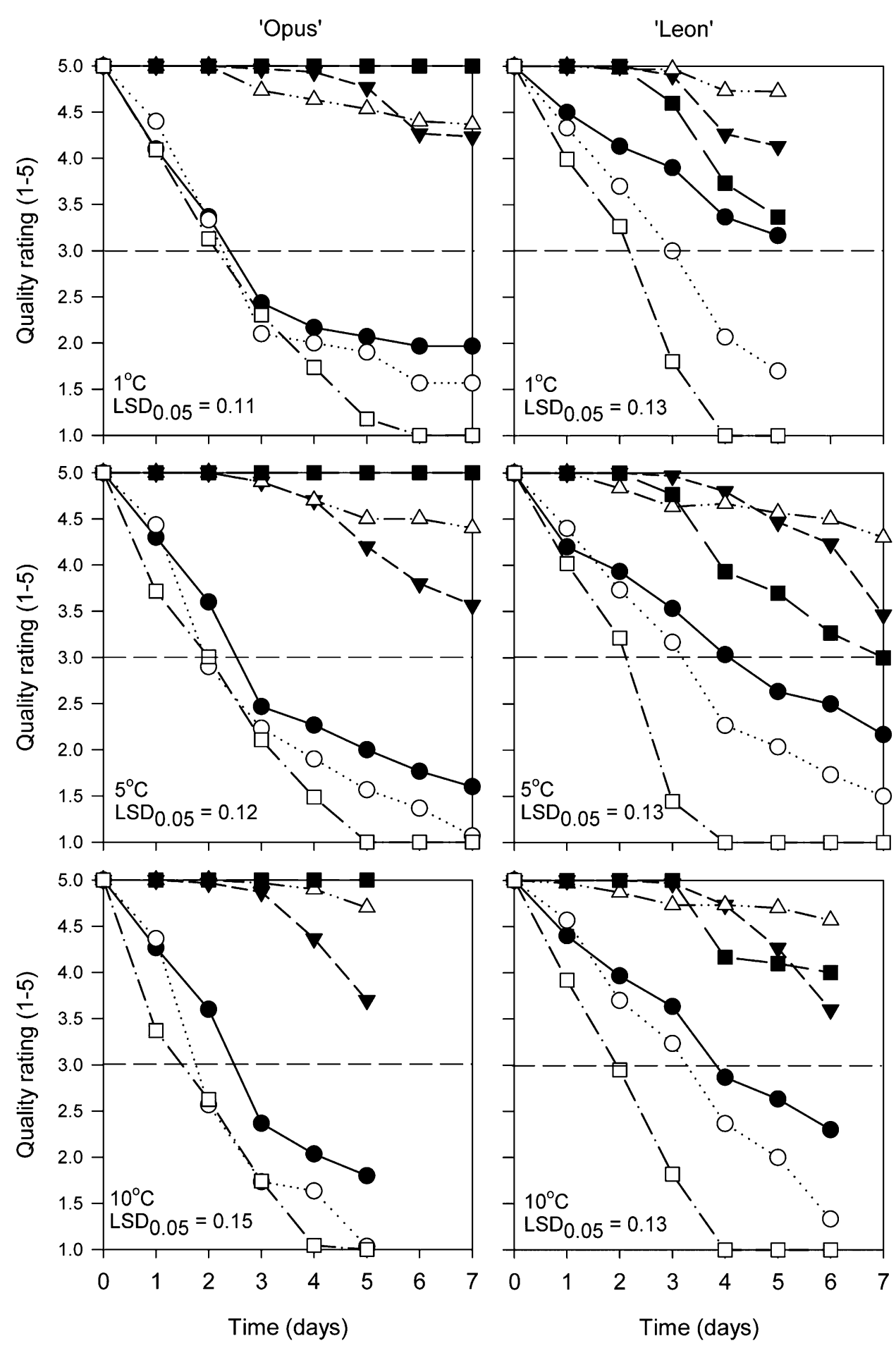

Fig. 1. Quality characteristics of 'Opus' and 'Leon' snap beans stored at chilling temperatures $\left(1,5\right.$, and $\left.10{ }^{\circ} \mathrm{C}\right)$. Chilling injury (CI) was evaluated after 1 additional day at $20^{\circ} \mathrm{C}$. Dashed strait line represents the minimum acceptable quality before snap beans become unmarketable (rating 3). Color ( $)$; firmness $(\bigcirc)$; shriveling $(\mathbf{\nabla})$; browning $(\triangle)$; CI $(\boldsymbol{\square})$; weight loss $(\square)$. Data points are means of three replicated samples of 15 snap beans each.

namely firmness, deteriorated faster than color. Others have also reported that during storage, the color of snap beans faded, the surface became leathery with slight and small depressions, flexibility increased, and the tips became discolored. Some snap bean pods also developed purple blemishes as the color faded or developed diagonal brown streaks. As the pod became yellow, the endocarp began to collapse and internal cavities formed (Watada and Morris, 1966b).
Browning or broken-end discoloration similar to that observed in snap beans stored at chilling temperatures may also occur as a result of injuries caused during harvest or when beans are held at ambient or under fluctuating temperatures (Henderson and Buescher, 1977; Nunes et al., 2001). Nevertheless, in the present study, browning of 'Opus' and 'Leon' snap beans stored at all temperatures never attained the limit of acceptability, remaining above a rating of 4 (slight to no browning) (Figs. 1 and 2). However, rusty spots started to develop after 1 additional day at $20{ }^{\circ} \mathrm{C}$ on the surface of 'Leon' snap bean pods stored for $2 \mathrm{~d}$ at 1 or $5{ }^{\circ} \mathrm{C}$ and for $3 \mathrm{~d}$ at $10{ }^{\circ} \mathrm{C}$ (Fig. 1). Groesche et al. (1966) also reported that when green beans were stored at temperatures below $7^{\circ} \mathrm{C}$ and then transferred to room temperature $\left(21{ }^{\circ} \mathrm{C}\right)$, russeting generally developed on the beans within $1 \mathrm{~d}$. After $24 \mathrm{~h}$ at $27{ }^{\circ} \mathrm{C}$, intentionally bruised beans were markedly 

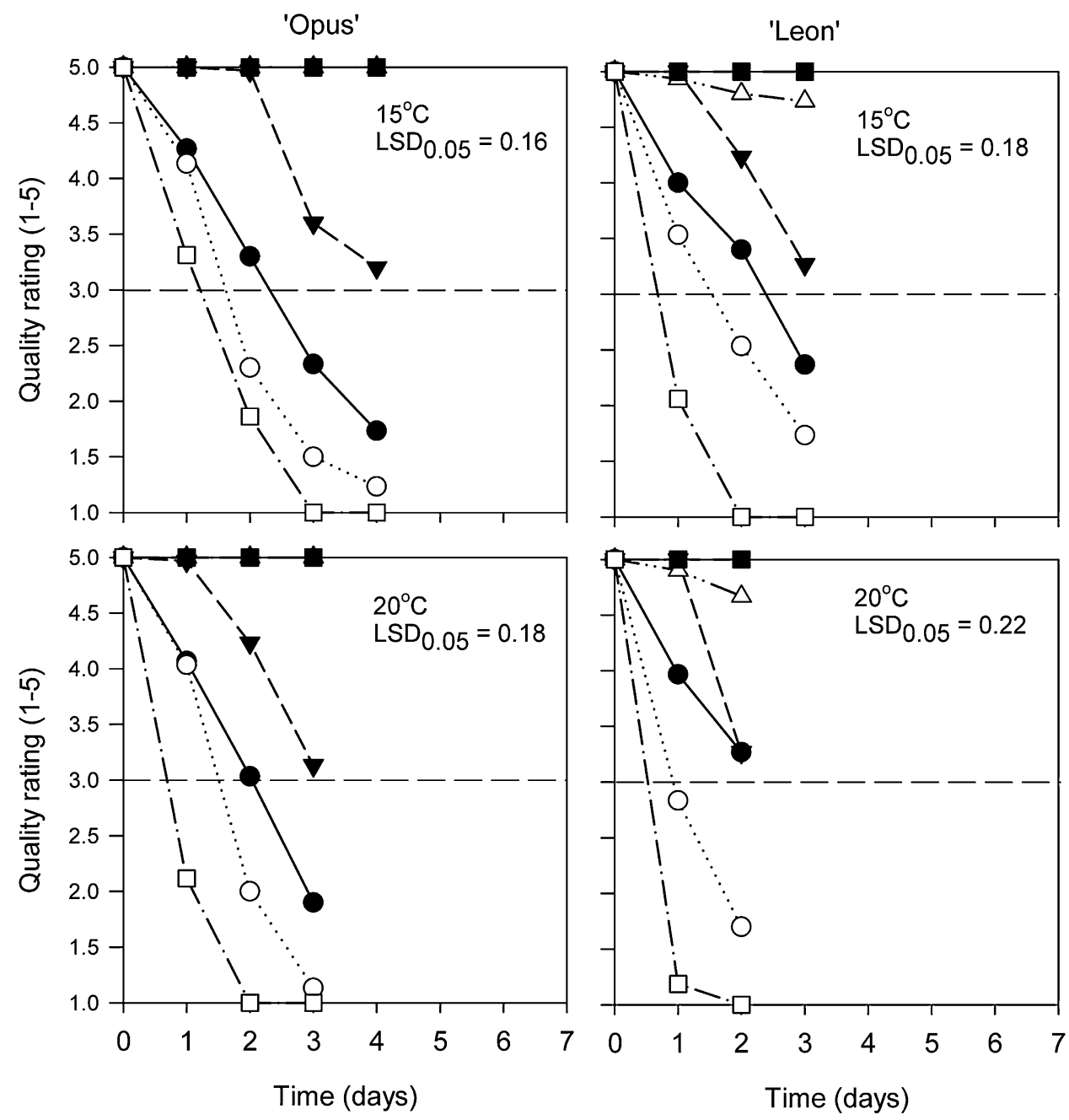

Fig. 2. Quality characteristics of 'Opus' and 'Leon' snap beans stored at non-chilling temperatures $\left(15\right.$ and $\left.20^{\circ} \mathrm{C}\right)$. Dashed strait line represents the minimum acceptable quality before snap beans become unmarketable (rating 3 ). Color $(\boldsymbol{O})$; firmness $(\bigcirc)$; shriveling $(\boldsymbol{\nabla})$; browning $(\triangle)$; chilling injury $(\boldsymbol{\square})$; weight loss ( $\square)$. Data points are means of three replicated samples of 15 snap beans each.

discolored (Henderson and Buescher, 1977) and when exposed to fluctuating temperature (from 4 to $23{ }^{\circ} \mathrm{C}$ ), browning significantly increased when compared with beans held at constant temperatures (Nunes et al., 2001). Henderson and Buescher (1977) showed that in broken pods, the increase in browning was associated with a $70 \%$ increase in soluble phenolic content, suggesting that discoloration in snap beans is associated with increased production of soluble phenolics, which are used in oxidative and condensation reactions to form brown-colored products.

Temperature had a significant impact on the loss of firmness of both snap beans cultivars. At the end of storage period, which lasted from 2 to $7 \mathrm{~d}$, depending on the cultivar and storage temperature, snap bean seeds were harder on the touch and the pods were softer and bent easily compared with at harvest when the pods were firm and snapped easily (Figs. 1 and 2). Firmness of 'Opus' snap beans reached the limit of acceptability after $\approx 2 \mathrm{~d}$ at $5{ }^{\circ} \mathrm{C}$ and after $\approx 1.5 \mathrm{~d}$ at 10,15 , and $20{ }^{\circ} \mathrm{C}$, whereas pods stored at $1{ }^{\circ} \mathrm{C}$ become soft and bent easily after $\approx 2.5 \mathrm{~d}$. After $\approx 1 \mathrm{~d}$ at $20{ }^{\circ} \mathrm{C}$ and $1.5 \mathrm{~d}$ at $15{ }^{\circ} \mathrm{C}$, firmness of 'Leon' snap beans attained the limit of acceptability, whereas firmness of snap beans stored at 1,5 , and $10^{\circ} \mathrm{C}$ attained the maximum acceptable limit after $\approx 3 \mathrm{~d}$ (Figs. 1 and 2). For pods stored at 1, 5, and $10{ }^{\circ} \mathrm{C}$, those held $5 \mathrm{~d}$ at $1{ }^{\circ} \mathrm{C}$ had more loss of firmness than those stored at 5 or $10{ }^{\circ} \mathrm{C}$. Softening, increased flabbiness, loss of turgidity, wilting and shriveling, and dryness are visual symptoms generally associated with loss of moisture (Nunes et al., 2007). In snap beans, loss of turgidity and crispness were previously attributed to the loss of water and an increase in soluble pectin (Sistrunk et al., 1989). In fact, in the present study, loss of water as expressed in terms of weight loss was significant for both snap bean cultivars stored at all temperatures (Fig. 4) and that might have contributed to the accelerated decrease in pod turgidity and firmness and overall loss of quality.

For both snap beans, shriveling did not reach the limit of acceptability (rating of 3 ) during the evaluation period (Figs. 1 and 2). Shriveling in both snap bean cultivars developed mostly at the bottom end of the pods causing a slight depression on the bean. Depending on the cultivar and storage tem- perature, at the end of the storage period, snap beans showed only slight or close to evident but not serious signs of shriveling (ratings between 4 and 3). However, shriveling severity tended to increase and developed faster with increasing temperature. After $3 \mathrm{~d}$, shriveling in 'Opus' snap beans stored at 15 and $20{ }^{\circ} \mathrm{C}$ was close to the limit of acceptability (Fig. 2), whereas after the same period of time, snap beans stored at lower temperatures showed almost no signs of shriveling (ratings higher than 4).

Opaque discoloration, pitting, and appearance of rusty brown spots are the most common symptoms of CI observed in snap beans exposed to temperatures below $5{ }^{\circ} \mathrm{C}$ (Cantwell and Suslow, 2010; Watada and Morris, 1966b). Depending on the cultivar and its susceptibility to CI, snap beans can be held for $\approx 2 \mathrm{~d}$ at $1{ }^{\circ} \mathrm{C}, 4 \mathrm{~d}$ at $2.5^{\circ} \mathrm{C}$, and 6 to $10 \mathrm{~d}$ at $5{ }^{\circ} \mathrm{C}$ before chilling symptoms become apparent (Cantwell and Suslow, 2010; Zong et al., 1992). Like for most chillingsensitive commodities, CI symptoms usually aggravate when snap beans are removed from the chilling temperature and transferred to a temperature close to ambient (Abou Aziz et al., 1976; Groesche et al., 1966; Watada 

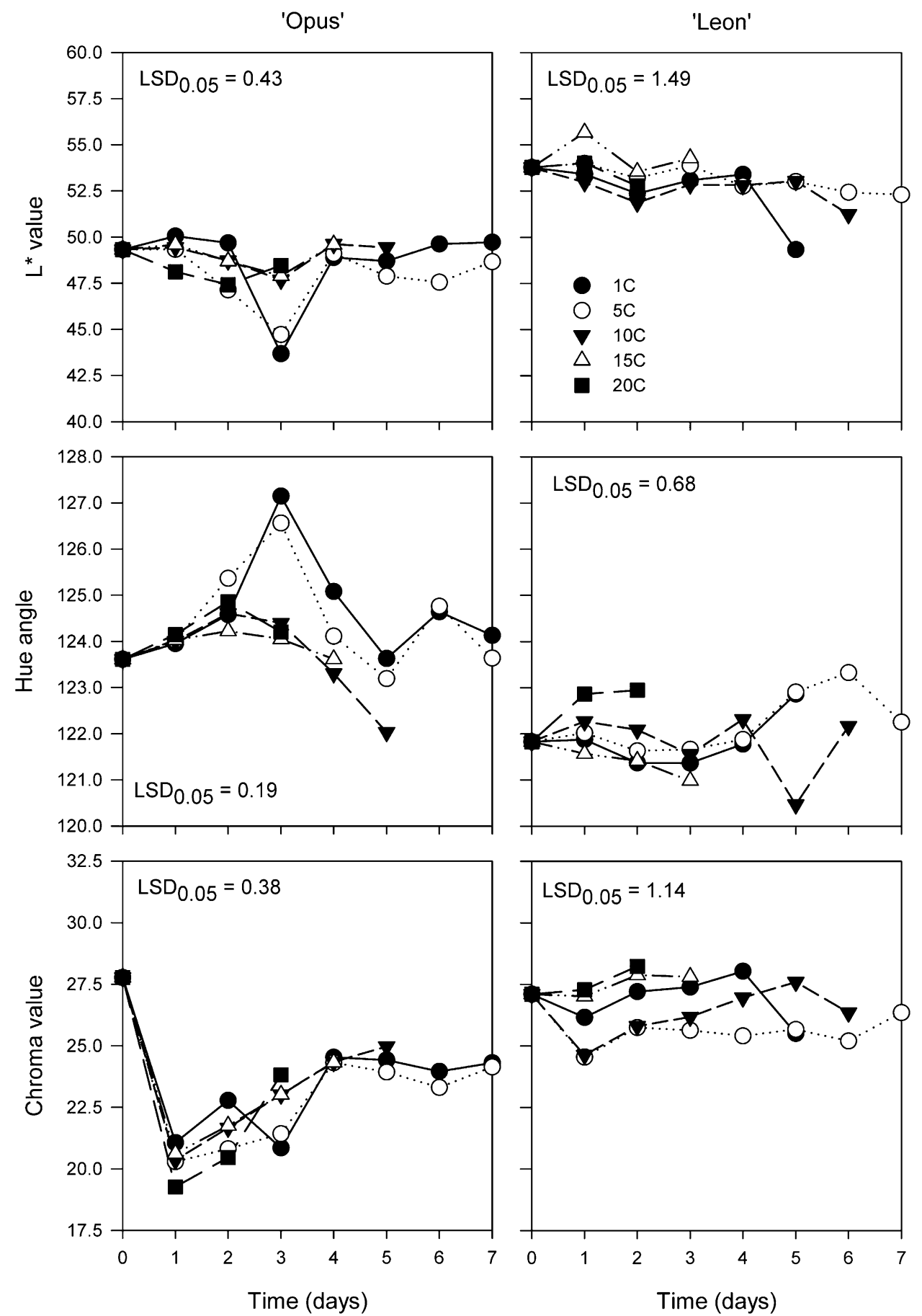

Fig. 3. Color ( $\mathrm{L}^{*}$, hue angle, and chroma) changes in 'Opus' and 'Leon' snap beans during storage at chilling $\left(1,5\right.$, and $\left.10{ }^{\circ} \mathrm{C}\right)$ or non-chilling $\left(15\right.$ and $\left.20{ }^{\circ} \mathrm{C}\right)$ temperatures. Data points are means of three replicated samples of 15 snap beans each.

and Morris, 1966b). In this study, after transfer to $20^{\circ} \mathrm{C}$ for 1 additional day, 'Opus' snap beans stored at 1,5 , and $10{ }^{\circ} \mathrm{C}$ showed no signs of CI, whereas 'Leon' snap beans developed trace to slight signs of CI (i.e., development of pitting and rusty spots) (Fig. 1). CI symptoms in 'Leon' snap beans started to be noticeable after exposure for $2 \mathrm{~d}$ at 1 or $5{ }^{\circ} \mathrm{C}$ and after $3 \mathrm{~d}$ at $10^{\circ} \mathrm{C}$ plus 1 additional day at $20{ }^{\circ} \mathrm{C}$ and then slightly increased during the remaining storage period. After $5 \mathrm{~d}$, CI symptoms were evident in pods stored at $1{ }^{\circ} \mathrm{C}$, and after $7 \mathrm{~d}$ at $5{ }^{\circ} \mathrm{C}$, CI reached the limit of acceptability.
Besides the development of visual CI symptoms observed in 'Leon' snap beans stored at temperatures lower than $15{ }^{\circ} \mathrm{C}$, softening and increased shriveling in pods stored at $1{ }^{\circ} \mathrm{C}$ compared with those stored at 5 and $10{ }^{\circ} \mathrm{C}$ might have been a result of the higher sensitivity of this cultivar to low storage temperature compared with 'Opus' snap beans. In fact, snap bean cultivars differ significantly in their susceptibility to CI (Abou Aziz et al., 1976; Gorini et al., 1974; Watada and Morris, 1966a, 1966b). For example, Gorini et al. (1974) reported a variation in the percentage of CI incidence in 17 different snap bean cultivars ranging from $0 \%$ to $42.5 \%$ when stored for $7 \mathrm{~d}$ at $4{ }^{\circ} \mathrm{C}$ and from $0 \%$ to $48.5 \%$ when stored at $7{ }^{\circ} \mathrm{C}$ for the same period of time. Furthermore, the same authors concluded that as a result of CI, some cultivars can only be stored for $2 \mathrm{~d}$, whereas others can be stored for $7 \mathrm{~d}$. In another study, 'Romano' snap beans were only slightly affected by a 14-d storage period at $5{ }^{\circ} \mathrm{C}$, because after transfer to $15{ }^{\circ} \mathrm{C}$, their postharvest life was reduced by only $3 \%$, whereas postharvest life of 'Top Crop' and 'Tendergreen' snap beans was reduced by $40 \%$ resulting from CI. Yet, the snap bean cultivars 

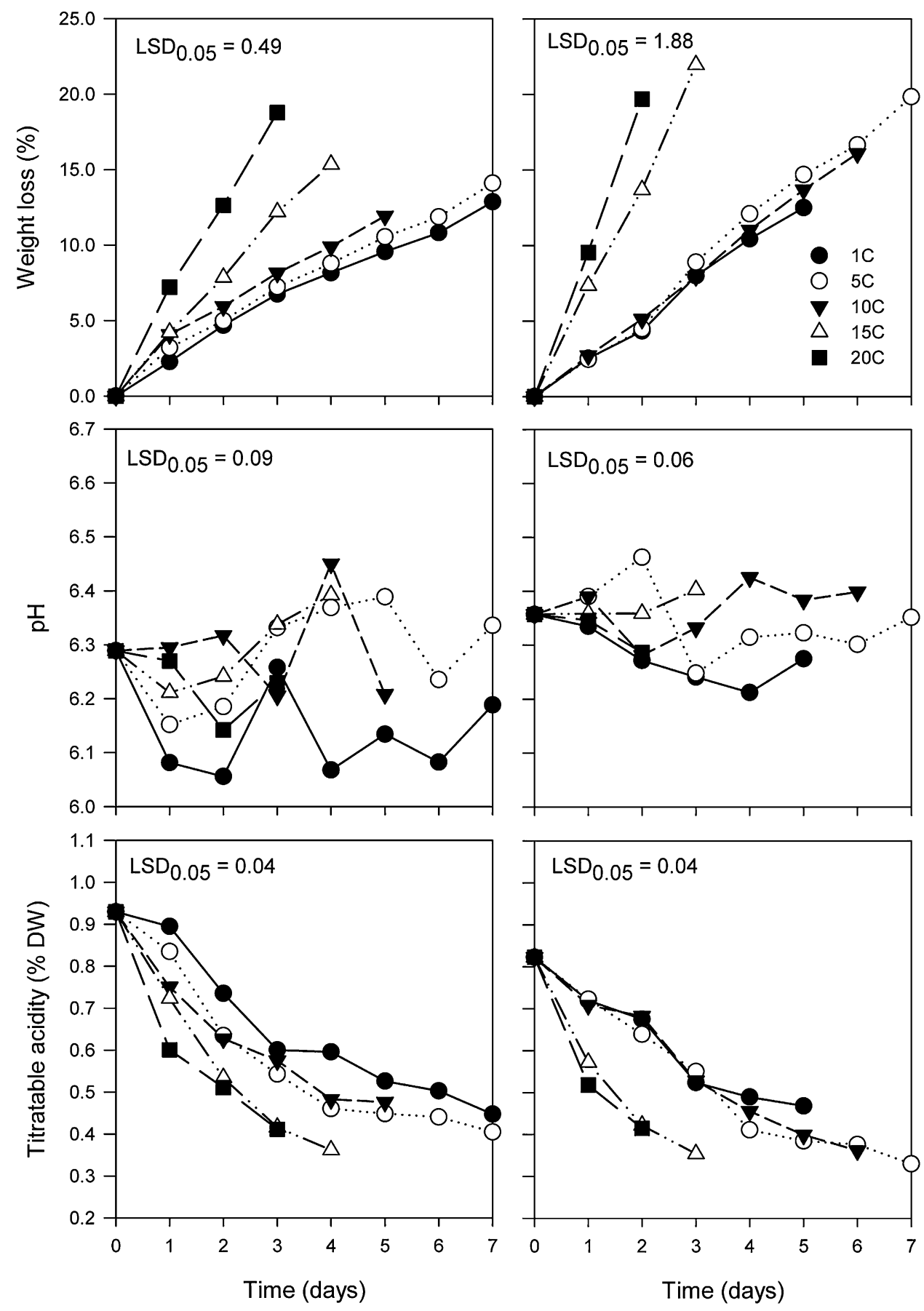

Fig. 4. Weight loss, $\mathrm{pH}$, and titratable acidity of 'Opus' and 'Leon' snap beans stored at chilling $\left(1,5\right.$, and $\left.10^{\circ} \mathrm{C}\right)$ or non-chilling $\left(15\right.$ and $\left.20^{\circ} \mathrm{C}\right)$ temperatures. Data points are means of three replicated samples of 15 snap beans each.

most affected by CI with a $60 \%$ reduction in their postharvest life, after transfer to $15{ }^{\circ} \mathrm{C}$, were 'Contender' and 'Kentucky Wonder 191' (Watada and Morris, 1966a). Likewise, although 'Opus' snap beans showed no signs of CI after storage for $7 \mathrm{~d}$ at $5^{\circ} \mathrm{C}$, after $7 \mathrm{~d}$, CI reached the limit of acceptability in 'Leon' snap beans stored under the same conditions. Nonetheless, no CI symptoms were observed in snap beans from both cultivars stored at 15 or $20{ }^{\circ} \mathrm{C}$ (Fig. 2).

Weight loss. Although by using clamshells and a protective plastic layer the humidity of the storage environment was maintained at levels $(90 \%$ to $94 \% \mathrm{RH})$ quite close to those recommended for snap beans $(95 \%$ to $100 \%$ $\mathrm{RH}$ ), weight loss of both snap bean cultivars increased considerably with storage time for all temperatures (Fig. 4). The rate of weight loss was however more important in 'Leon' than in 'Opus' snap beans. According to Robinson et al. (1975), snap beans are considered unacceptable for sale after a weight loss greater than $5 \%$ as a result of loss of moisture. Although in this study, weight loss of snap beans from both cultivars attained 5\% after less than $1 \mathrm{~d}$ at $20^{\circ} \mathrm{C}$, shriveling became evident only after $1 \mathrm{~d}$ of storage (Fig. 2), which corresponded to a weight loss of $7.2 \%$ and $9.5 \%$ for 'Opus' and 'Leon', respectively. For 'Opus' snap beans, by the time shriveling rating was close to the limit of acceptability, after $3 \mathrm{~d}$ at $20{ }^{\circ} \mathrm{C}$, weight loss had attained $\approx 13 \%$. For 'Leon' snap beans, shriveling became close to the limit of acceptability after $2 \mathrm{~d}$ at $20{ }^{\circ} \mathrm{C}$, which corresponded to a weight loss of $\approx 20 \%$. Others have reported that before shriveling symptoms were noted, an average of $32 \%$ of the initial snap beans 
weight was lost (Hruschka, 1977). The large divergence between weight losses and the onset of the development of visual symptoms related to loss of water might be explained by differences in cultivar morphology (i.e., thickness of the epidermal and hypodermal layers) and maturity at harvest (Reeve and Brown, 1968).

Snap beans from both cultivars stored at 1 , 5 , or $10^{\circ} \mathrm{C}$ had similar weight losses up to $2 \mathrm{~d}$ of storage in which weight loss attained $\approx 5 \%$ (Fig. 4). However, after $5 \mathrm{~d}$, weight loss of 'Leon' was significantly higher than that of 'Opus' snap beans. That is, weight loss for 'Opus' stored at 1,5 and $10{ }^{\circ} \mathrm{C}$ for $5 \mathrm{~d}$ was $\approx 9.6 \%, 10.5 \%$, and $12.0 \%$, respectively, whereas weight loss for 'Leon' was $12.5 \%$, $14.7 \%$, and $13.7 \%$ after $5 \mathrm{~d}$ at 1,5 , and $10{ }^{\circ} \mathrm{C}$, respectively. Furthermore, after $7 \mathrm{~d}$ at $5{ }^{\circ} \mathrm{C}$, 'Leon' showed a significant higher weigh loss $(20 \%)$ than 'Opus' $(14 \%)$. This point corresponded to the time that CI symptoms had attained the limit of acceptability. Exposure of snap beans to chilling temperatures (i.e., 1 or $5{ }^{\circ} \mathrm{C}$ ) might have resulted in loss of cell membrane integrity and leakage of solutes and water, which often leads to manifestation of CI symptoms such as pitting and wilting (Kays, 1991). The development of CI symptoms in 'Leon' snap beans might have been a result of sensitivity of this cultivar to chilling temperatures, but CI symptoms might have also been aggravated by the higher water loss when compared with 'Opus' snap beans. Thus, exposure to chilling temperatures most likely led to the development of pitting and consequently water leakage from the cells and, in turn, excessive water loss might have aggravated the CI symptoms observed in 'Leon' snap beans. Fonseca and Cinco (2006) also suggested that water loss in cucumber and zucchini was a potential trigger to the development of pitting. In fact, postharvest pitting was eliminated when produce was exposed to either high humidity levels ( $99 \%$ to $100 \% \mathrm{RH})$ or bagged. Furthermore, Purvis (1995) reported that development of CI symptoms in some lines of Cucumis sativus fruit, during storage at $5{ }^{\circ} \mathrm{C}$ for $5 \mathrm{~d}$, was highly correlated with weight loss.

Because weight loss for both 'Opus' and 'Leon' snap bean cultivars was very substantial during storage, percentage of weight loss was converted to a 1 to 5 rating scale in which the limit of acceptability was set at 5\% (maximum acceptable weight loss reported in the literature) to be comparable to the sensory quality attributes evaluated. Therefore, weight loss was in most cases the first attribute to reach the limit of acceptability (Figs. 1 and 2 ). Thus, after $\approx 2 \mathrm{~d}$, weight loss attained the limit of acceptability for 'Opus' and 'Leon' snap beans stored at 1, 5, and $10{ }^{\circ} \mathrm{C}$ and after $1 \mathrm{~d}$ or less than $1 \mathrm{~d}$ for beans stored at 15 and $20^{\circ} \mathrm{C}$, respectively. Excessive weight loss from horticultural commodities often leads to loss of quality resulting from softening and shriveled or wilted appearance. Nunes et al. (2007) found a significant linear correlation between weight loss and visual quality attributes such as firmness, shriveling, and color changes in snap beans, and the higher the weight loss, the softer and more yellowish and shriveled the pods were. Similarly, in this study, a significant negative linear correlation was found between weight loss and color, firmness, and shriveling $(P<$ 0.001 ) for both 'Opus' and 'Leon' snap beans as well as a significant negative linear correlation between weight loss and CI $(P<0.01)$ for 'Leon' snap beans. That is, the higher the percentage of weight loss, the lower the quality ratings for color, firmness, shriveling, and CI. Nonetheless, deterioration of sensory quality may not be exclusively attributed to water loss, but rather to a summation of many appearance defects, some of which may result from loss of water (Nunes et al., 2007).

The rate of transpiration, and thus loss of moisture, can be reduced by raising the $\mathrm{RH}$; lowering the air temperature; minimizing the difference between the air and the temperatures of snap beans; reducing air movement; and by protective packaging. In this study, although double protection was used (clamshells and plastic layer) with the purpose of increasing the $\mathrm{RH}$ and thus preventing water loss, the significant weight loss obtained for all temperatures suggests that the use of a film wrapping might have been more suitable. In fact, the use of film wrapping creates a higher $\mathrm{RH}$ (close to $100 \%$ ) in the environment and consequently helps to reduce loss of moisture during storage. However, fungal decay may constitute a problem when fruits and vegetables are exposed to high temperatures combined with high humidity levels (Nunes, 2008b).

$\mathrm{pH}$ and titratable acidity. Initial $\mathrm{pH}$ of snap beans cultivars was equivalent, $\approx 6.3$ for 'Opus' and 6.4 for 'Leon' (Fig. 4). These values are similar to those previously reported in the literature (Groesche et al., 1966; Martinez et al., 1995). Snap bean $\mathrm{pH}$ was slightly affected by storage time and temperature; that is, by the end of the storage period, $\mathrm{pH}$ of snap beans were similar to those at harvest. However, $\mathrm{pH}$ of snap beans stored at $1{ }^{\circ} \mathrm{C}$ tended to decline during storage compared with the $\mathrm{pH}$ of snap beans from other temperatures. In an earlier study, Groesche et al. (1966) also reported no change in the $\mathrm{pH}$ value of 'Harvester' and 'Tendergreen' snap beans stored for $14 \mathrm{~d}$ at $7.5^{\circ} \mathrm{C}$. However, acidity of cellular sap was greater in beans exposed to 0 or $3{ }^{\circ} \mathrm{C}$ than those exposed at $10^{\circ} \mathrm{C}$ (Burzo et al., 1994).

On a fresh weight basis, initial titratable acidity (TA) expressed as percentage of malic acid, the main organic acid in snap beans (Martinez et al., 1995), was $0.09 \%$ for snap beans cv. Opus and $0.08 \%$ for cv. Leon (data not shown). TA, expressed on a dry weight basis, significantly decreased during storage in both snap bean cultivars regardless of the storage temperature (Fig. 4). However, decrease in TA was higher and faster in beans stored at 15 and $20^{\circ} \mathrm{C}$ than in those stored at lower temperatures. For example, after $2 \mathrm{~d}$ at $20{ }^{\circ} \mathrm{C}$, there was an average reduction of $\approx 48 \%$ in snap bean TA, whereas after $2 \mathrm{~d}$ at $1{ }^{\circ} \mathrm{C}$, TA was reduced by an average of $\approx 19 \%$.
Soluble solids content. Initial SSC was slightly higher in 'Opus' than in 'Leon' snap beans (Fig. 5). At the time of harvest, SSC on a fresh weight basis of 'Opus' and 'Leon' beans was $\approx 5 \%$ and $4.5 \%$, respectively, which are values comparable to those found in the literature (Trail et al., 1992). During storage, snap beans from all temperatures showed a significant decrease in their initial SSC. After $2 \mathrm{~d}$ at $20{ }^{\circ} \mathrm{C}$, both snap bean cultivars showed a reduction of $\approx 52 \%$ on their initial SSC. Decline in SSC content of beans stored at 1,5 , and $10{ }^{\circ} \mathrm{C}$ followed the same trend for both cultivars. However, after $5 \mathrm{~d}$, the average decrease in SSC was slightly greater in 'Leon' (50\%) compared with 'Opus' (47\%). At the end of the 7-d period, 'Opus' stored at $5{ }^{\circ} \mathrm{C}$ showed a $51 \%$ decrease in their initial SSC, whereas 'Leon' snap beans stored under the same conditions showed a reduction of $58 \%$ in their initial SSC. A significant decrease in SSC was also observed in snap beans after storage for 8 to $16 \mathrm{~d}$ at $5{ }^{\circ} \mathrm{C}$ compared with $4 \mathrm{~d}$ at the same temperature (Trail et al., 1992).

The significant reduction in TA and SSC for snap beans exposed to higher temperatures compared with that observed at lower temperatures was most likely the result of the depletion of the sugar and acid reserves that results from an increase in fruit respiration metabolism, which involves the consumption of simple sugars and organic acids (Kays and Paull, 2004; Will et al., 2007).

Total ascorbic acid content. Ascorbic acid (AA) content significantly decreased during storage in both snap bean cultivars at all storage temperature (Fig. 5). On a fresh weigh basis, initial AA content was $13.8 \mathrm{mg} /$ $100 \mathrm{~g}$ for $\mathrm{cv}$. Opus and $12.7 \mathrm{mg} / 100 \mathrm{~g}$ for $\mathrm{cv}$. Leon (data not shown). Research conducted by Favell (1998) showed similar AA contents, which ranged from 12 to $15 \mathrm{mg} / 100 \mathrm{~g}$ in garden fresh green beans. Good temperature management is known to be the best way to maintain AA content of fruit and vegetables (Lee and Kader, 2000). In fact, in the present study, loss of AA increased as the temperature increased. After only $1 \mathrm{~d}$ at $20^{\circ} \mathrm{C}$, 'Opus' and 'Leon' snap beans had lost $\approx 44 \%$ and $55 \%$ of their initial AA content, respectively. Similarly, Favell (1998) report a loss of $30 \%$ on the initial AA content of snap beans after storage for $1 \mathrm{~d}$ at ambient temperature $\left(20{ }^{\circ} \mathrm{C}\right)$. After $3 \mathrm{~d}$, AA content of 'Opus' snap beans stored at $1{ }^{\circ} \mathrm{C}$ was significantly higher $(80.4 \mathrm{mg} / 100 \mathrm{~g})$ than that of beans store at higher temperatures (e.g., 66.3, 63.2 , and $40.5 \mathrm{mg} / 100 \mathrm{~g}$ at 5,15 , and $20^{\circ} \mathrm{C}$, respectively). Conversely, the AA content of 'Leon' snap beans stored at 1,5 , and $10{ }^{\circ} \mathrm{C}$ was not significantly different after $3 \mathrm{~d}$ of storage $(73.7,70.0$, and $68.4 \mathrm{mg} / 100 \mathrm{~g}$, respectively), yet at $15{ }^{\circ} \mathrm{C}$, AA was significantly lesser (43.6 mg/100 g) compared with lower temperatures. Furthermore, after $5 \mathrm{~d}$ at $5{ }^{\circ} \mathrm{C}$, AA content of 'Opus' snap beans was $\approx 69 \%$ of its initial content, whereas for 'Leon', AA content was reduced by $\approx 72 \%$.

$\mathrm{Wu}$ et al. (1992) reported that $\approx 58 \%$ of the initial AA content of green beans was lost 

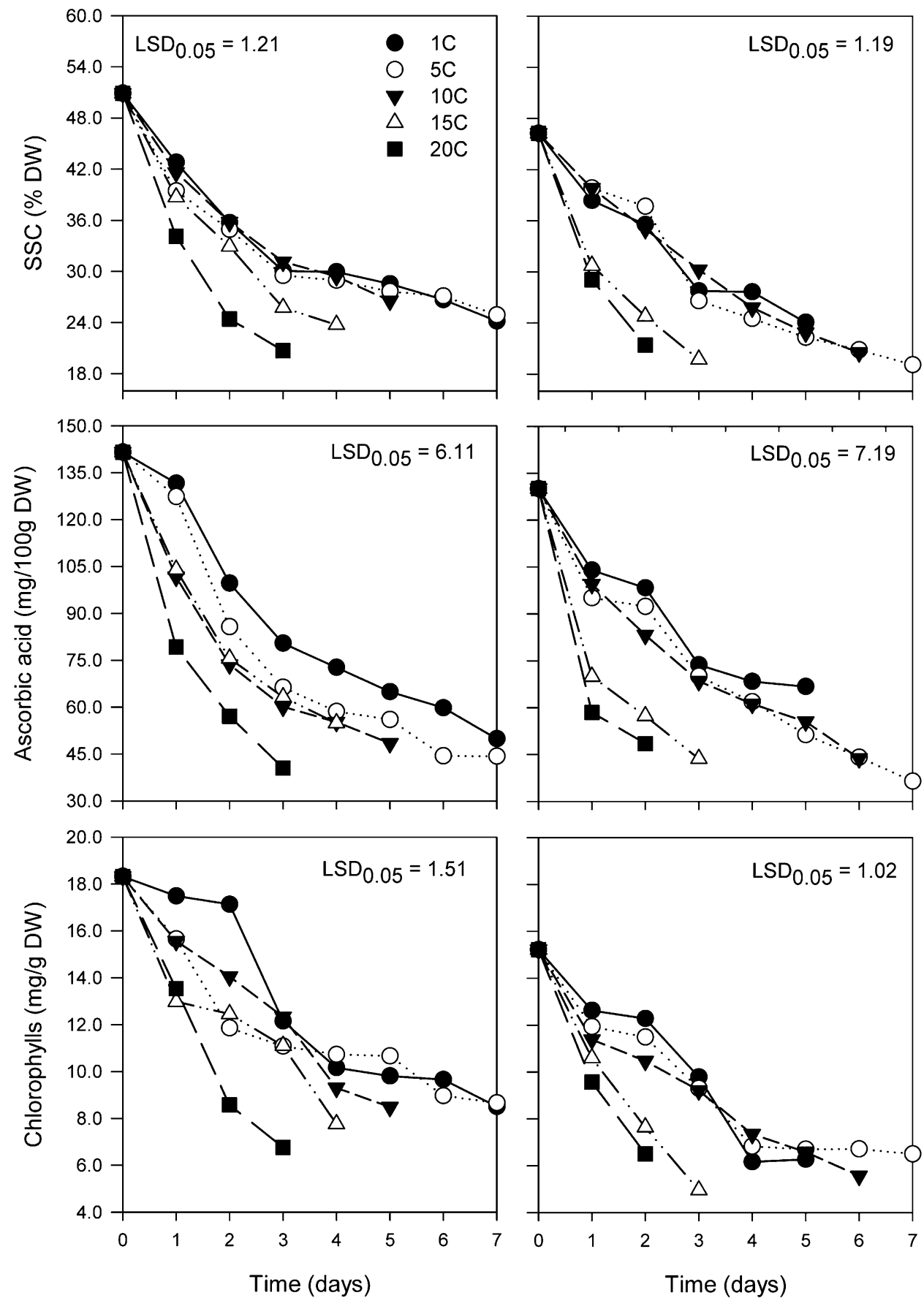

Fig. 5. Soluble solids (SSC), total ascorbic acid, and total chlorophylls contents of 'Opus' and 'Leon' snap beans stored at chilling $\left(1,5\right.$, and $\left.10{ }^{\circ} \mathrm{C}\right)$ or non-chilling $\left(15\right.$ and $20^{\circ} \mathrm{C}$ ) temperatures. Data points are means of three replicated samples of 15 snap beans each.

during the first $3 \mathrm{~d}$ of exposure to $4{ }^{\circ} \mathrm{C}$, attributable most likely to an accelerated enzymatic and non-enzymatic degradation. Likewise, initial content of AA of 'Blue Lake' green beans was reduced by more than $70 \%$ after storage for 1 week at $4{ }^{\circ} \mathrm{C}$. After $16 \mathrm{~d}$ at $4{ }^{\circ} \mathrm{C}$, the initial concentration of AA $(15.2 \mathrm{mg} / 100 \mathrm{~g}$ fresh weight) was reduced to $1.3 \mathrm{mg} / 100 \mathrm{~g}$ fresh weight (Howard et al., 1999). As reported by Miller and Heilman (1952), CI causes accelerated losses in AA content of chilling-sensitive crops, yet destruction of AA can occur before any visible symptoms of chilling develop. Overall, loss of AA content in 'Leon' beans stored at 1 and $5{ }^{\circ} \mathrm{C}$ was greater than in 'Opus', possibly as a result of the increased weight loss combined with the higher chilling sensitivity of 'Leon' compared with 'Opus'. In fact, as reported by Lee and Kader (2000), during the postharvest period, any conditions favorable to water loss result in a rapid loss of AA. Nunes et al. (1998) reported that strawberries may lose AA rapidly as a consequence of tissue damage, like such occurring in snap beans resulting from $\mathrm{CI}$, which may lead to increased water loss and allow exposure of AA to oxidation. Also, ascorbate oxidase, normally bound to the cell walls, might be released after tissue damage or water loss. Therefore, water loss combined with tissue damage resulting from exposure to chilling temperatures might have contributed to an increased loss in AA content of snap beans 'Leon' compared with 'Opus'.

Chlorophyll content. Chlorophyll content of snap beans decreased continuously during storage, regardless of the temperature (Fig. 5). On a fresh weight basis, initial chlorophyll content was higher in snap 'Opus' snap beans $(18.3 \mathrm{mg} / \mathrm{g})$ when compared with 'Leon' $(15.2 \mathrm{mg} / \mathrm{g})$ (data not shown). In fact, results 
from color evaluations also confirmed that 'Opus' snap beans were deeper green compared with 'Leon' snap beans (Figs. 1 and 3). Besides, a high negative correlation $(P<$ 0.05 ) was obtained between visual color scores and chlorophyll content for both snap beans cultivars stored at different temperatures. That is, chlorophyll content significantly decreased as the color of the snap bean pods turned from a bright green to a more yellowish green color. However, no significant correlation $(P>0.05)$ was found between $\mathrm{L}^{*}$, hue, or chroma and chlorophyll content for 'Opus' and 'Leon' snap beans stored at different temperatures, most likely because instrumental color was measured only in a small area of the pod, whereas, although subjective, visual observations covered the entire pod, and besides, chlorophyll content was measured using tissue from whole snap bean pods.

After $2 \mathrm{~d}$ of storage at $20^{\circ} \mathrm{C}$, 'Opus' snap beans had lost $53 \%$ of their initial chlorophylls content, whereas chlorophylls content of 'Leon' decreased by 57\%. 'Opus' snap beans maintained better chlorophyll content during the first $2 \mathrm{~d}$ of storage compared with 'Leon'. Although in a previous study chlorophyll content of snap beans stored at 8 or $10{ }^{\circ} \mathrm{C}$ increased during a short 4- to 6-d storage period, longer exposure times also led to significant reduction in the chlorophyll levels of snap beans (Cano et al., 1998; Trail et al., 1992). Storage of green beans at 4,8 , or $12{ }^{\circ} \mathrm{C}$ for $15 \mathrm{~d}$, followed by transfer to $20^{\circ} \mathrm{C}$, resulted in a reduction of chlorophylls content of $\approx 33 \%$ to $47 \%$ compared with initial values (Monreal et al., 1999), whereas snap beans stored at $7{ }^{\circ} \mathrm{C}$ followed by transfer to $20{ }^{\circ} \mathrm{C}$ retained $68 \%$ of their initial chlorophylls content (Groesche et al., 1966). Similarly, in the present study, chlorophyll content of snap beans stored at 1 and $5{ }^{\circ} \mathrm{C}$ decreased during the first $4 \mathrm{~d}$ of storage, but after that time, chlorophyll losses tended to stabilize. After $5 \mathrm{~d}$ of storage at 1,5 , and $10^{\circ} \mathrm{C}$, chlorophyll content of 'Opus' snap beans decreased by $44 \%, 41 \%$, and $54 \%$, respectively, whereas after the same storage time, chlorophyll content of 'Leon' stored at the same temperatures decreased by $59 \%, 57 \%$, and $56 \%$. Like that observed for AA, the higher loss of chlorophylls in 'Leon' compared with 'Opus' suggests that chlorophyll degradation might have also been accelerated as a consequence of increased water loss combined with the chilling sensitivity of 'Leon' when stored at 1,5 , and $10{ }^{\circ} \mathrm{C}$. As reported by Monreal et al. (1999), greater chlorophyll losses in snap beans exposed to chilling temperatures may be an indicator that CI could induce severe damage in the chloroplast membranes and accelerate the degradative pathways of pigments, resulting in loss of chlorophylls. Therefore, chlorophyll degradation could be used as an indicator of loss of quality in snap beans during storage at different temperatures. Storage at high temperatures may affect the respiration rate of the tissue and accelerate the degradative process, whereas chilling temperatures (below $7{ }^{\circ} \mathrm{C}$ ) can result in increased pigment degradation resulting from chilling damage (Monreal et al., 1999).

Limiting quality factors and remaining compositional value. In a previous study, Martinez et al. (1995) reported that the relative importance of color, hardness, juiciness, and fibrousness in predicting acceptance of green beans was $2 \%, 19 \%, 31 \%$, and $33 \%$, respectively, and suggested that texture attributes are the most important factors determining green been acceptance. In a recent study, Kahn and McGlynn (2009) suggested that snap bean color is not the major selection attribute, but only one of the many criteria considered by consumers when selecting fresh green beans. In this study, weight loss (on a 1 to 5 rating scale) was the first and only non-sensory quality attribute to attained the limit of acceptability for 'Opus' snap beans stored at 15 and $20{ }^{\circ} \mathrm{C}$ and for 'Leon' stored at all temperatures. Although the amount of weight lost by a particular fruit or vegetable during storage is impossible to quantify visually, it may lead to a variety of visual and tactile quality changes, namely softening, shriveling, and color changes. Consequently, firmness was the first sensory quality attribute, followed by color, to reach maximum acceptable scores and therefore limited the shelf life of 'Opus' and 'Leon' snap beans stored at different temperatures. Shelf life of both snap bean cultivars was relatively short regardless of the storage temperature resulting from increased water loss and accelerated softening of the pods during storage. Although CI might have indirectly affected the quality of 'Leon', it was not considered a sensory quality limiting factor for pods stored at 1 and $5{ }^{\circ} \mathrm{C}$. Furthermore, CI did not contribute to a reduction in the shelf life of 'Leon' snap beans at 1 and $5{ }^{\circ} \mathrm{C}$ when compared with storage at 15 and $20^{\circ} \mathrm{C}$. The much shorter shelf life of 'Opus' and 'Leon' snap beans ( 2 to $3.5 \mathrm{~d}$ ), particularly when stored within the recommended range of temperatures $\left(5\right.$ to $\left.7.5^{\circ} \mathrm{C}\right)$, compared with longer shelf life ( 8 to $12 \mathrm{~d}$ ) for snap beans reported in the literature (Cantwell and Suslow, 2010; Monreal et al., 1999) can be related to multiple factors. First, the criteria used to determine the end of shelf life or the minimum acceptable quality used by others might not have been as conservative as the one used in this study. In this study, a rating of 3 (acceptable quality) was established to be the limit of acceptability (i.e., below this rating, a selective consumer would have not bought the snap beans) when at this rating maybe others would have considered that quality was still good. Second, the great amount of weight loss might have also contributed to a reduction in shelf life and overall quality acceptability although snap beans were kept inside protective packaging. Lastly, cultivar variations and conditions during growing and harvest, among others, might have also summed up to the factors mentioned.

In snap beans stored at $1{ }^{\circ} \mathrm{C}$, loss of firmness and changes in color were simultaneously the main sensory quality attributes that limited the shelf life of 'Opus', whereas loss of firmness was the primary quality limiting factor for 'Leon'. Therefore, after $\approx 2.5$ and $3 \mathrm{~d}$ at $1{ }^{\circ} \mathrm{C}$, 'Opus' and 'Leon' snap beans, respectively, were considered unacceptable for sale as a result of the development of objectionable color and considerable softening of the pods (Fig. 1). By the time the sensory quality of snap beans stored at $1{ }^{\circ} \mathrm{C}$ attained the limit of acceptability, the remaining SSC was $70 \%$ and $60 \%$ for 'Opus' and 'Leon', respectively. At the same time, the remaining AA content was $70 \%$ for 'Opus' and 57\% for 'Leon'.

In snap beans stored at 5 and $10^{\circ} \mathrm{C}$, loss of firmness was the main sensory quality attribute that limited the shelf life of 'Opus' and 'Leon' to 2 and $3.5 \mathrm{~d}$, respectively (Fig. 1). Although loss of firmness was the main sensory quality factor that limited the shelf life of the snap beans stored at 5 and $10{ }^{\circ} \mathrm{C}$, color could also be considered as an important limiting quality factor reaching a maximum acceptable after 2.5 and $4 \mathrm{~d}$ in 'Opus' and 'Leon', respectively. For 'Leon' stored at $5{ }^{\circ} \mathrm{C}$, CI was also important if snap beans were to be stored for more than $7 \mathrm{~d}$ at this temperature (Fig. 1). By the time the sensory quality of snap beans stored at $5{ }^{\circ} \mathrm{C}$ attained the limit of acceptability, the remaining SSC was $69 \%$ and $58 \%$ of original SSC for 'Opus' and 'Leon', respectively. At the same time, the remaining AA content was $61 \%$ for 'Opus' and $52 \%$ for 'Leon'. In snap beans stored at $10{ }^{\circ} \mathrm{C}$, remaining SSC was $71 \%$ for 'Opus' and $65 \%$ for 'Leon'; AA retention was $52 \%$ for 'Opus' and $53 \%$ for 'Leon' by the time sensory quality attained minimum acceptable scores.

After only $1.5 \mathrm{~d}$ at $15{ }^{\circ} \mathrm{C}$, loss of firmness had reached minimum acceptable scores and therefore limited the marketability of both snap beans cultivars (Fig. 2). Although undesirable changes in the color of snap beans occurred after loss of firmness was objectionable, color might also be considered an important quality factor because it reached an acceptable maximum after $\approx 2.5 \mathrm{~d}$ for both cultivars. By the time the sensory quality of snap beans stored at $15{ }^{\circ} \mathrm{C}$ was considered unacceptable, the remaining SSC was $75 \%$ and $65 \%$ for 'Opus' and 'Leon', respectively. At the same time, the remaining AA content was $73 \%$ for 'Opus' and $44 \%$ for 'Leon'

Loss of firmness was the first sensory quality attribute to reach maximum acceptable scores after 1.5 and $1 \mathrm{~d}$ in 'Opus' and 'Leon' snap beans stored at $20{ }^{\circ} \mathrm{C}$, respectively (Fig. 2). At this temperature, by the time sensory quality was considered objectionable, the remaining SSC was $67 \%$ for 'Opus' and $45 \%$ for 'Leon'; AA retention was $56 \%$ for 'Opus' and $53 \%$ for 'Leon'.

Although based on the sensory quality attributes evaluated in this study, 'Leon' had a longer shelf life compared with 'Opus' when stored at 1,5 , and $10{ }^{\circ} \mathrm{C}$, the remaining SSC and AA content was lower than in 'Opus' stored at the same temperatures. This may be explained by the increased loss of water and the chilling sensitivity of 'Leon' 
compared with 'Opus'. Although CI symptoms that developed during storage did not affect significantly the overall appearance of the pods compared with loss of firmness, exposure to chilling temperatures most likely accelerated the loss of sugars (SSC) and ascorbic acid. On the other hand, when stored at 15 and $20^{\circ} \mathrm{C}$, the shelf life of 'Leon' was similar or slightly shorter than that of 'Opus', but the remaining SSC and AA content was higher in 'Opus' than in 'Leon'. Overall, the remaining SSC and AA content were lower in 'Leon' snap beans ( $45 \%$ to $65 \%$ and $44 \%$ to $57 \%$ for SSC and AA, respectively) than in 'Opus' (67\% to $75 \%$ and $52 \%$ to $73 \%$ for SSC and AA, respectively) stored at the same temperatures.

\section{Conclusions}

Temperature had a significant effect on the shelf life and overall sensory and compositional quality of both snap bean cultivars. In general, the higher the storage temperature, the faster the deterioration of the snap bean pods, regardless of the cultivar. Snap beans stored at temperatures higher than $10{ }^{\circ} \mathrm{C}$ were less green, softer, and more shriveled, had higher weight loss, and lower acidity, SSC, AA, and chlorophyll content than those stored at lower temperatures. However, when stored at 1,5 , and $10{ }^{\circ} \mathrm{C}$ 'Leon' snap beans developed CI symptoms, whereas no symptoms were noticeable in 'Opus' snap beans. Although CI might have indirectly affected the quality of 'Leon', it was not considered a sensory quality limiting factor for pods stored at 1 and $5{ }^{\circ} \mathrm{C}$. Furthermore, CI did not contribute to a reduction in the shelf life of 'Leon' snap beans stored at 1 and $5{ }^{\circ} \mathrm{C}$ when compared with storage at 15 and $20^{\circ} \mathrm{C}$. Overall, weight loss was the first non-sensory quality attribute to reach the limit of acceptability, whereas firmness was the first sensory quality attribute, followed by color, to reach maximum acceptable scores and therefore limited the shelf life of 'Opus' and 'Leon' snap bean cultivars stored at different temperatures. Shelf life of both snap bean cultivars was relatively short ranging from 1 to $3.5 \mathrm{~d}$, depending on the temperature and cultivar, as a result of excessive water loss and accelerated softening of the pods during storage. Furthermore, when snap beans reached the minimum acceptable sensory quality, reduction in SSC and AA content was already considerable. The significant weight loss obtained for all temperatures suggests that the use of a film wrapping rather than clamshells should be beneficial because it would create a high $\mathrm{RH}$ in the environment and therefore reduce water loss, maintain better overall quality, and extend the shelf life of snap beans.

\section{Literature Cited}

Abou Aziz, A.B., M.M.A. Maksoud, K.A.A. Salam, and A.S.A. Kader. 1976. Comparative studies on the effect of storage temperature on quality and decay percentage of leguminous fruits. Egypt. J. Hort. 3:189195.

Burzo, I., A. Amariueti, and C. Craciun. 1994 Effect of low temperature on some physiological and ultrastructural changes of sweet pepper, eggplants and pod beans. Acta Hort. 368: 598-607.

Cain, R.F., A.P. Sidwell, and W.A. Frazier. 1953. Field behavior and processing characteristics of Blue Lake beans. Oreg. Agric. Exp. Stn. Misc. Paper No. 6.

Cano, M.P., M. Monreal, B. de Ancos, and R. Alique. 1998. Effects of oxygen levels on pigment concentrations in cold-stored green beans (Phaseolus vulgaris L. cv. Perona). J. Agr. Food Chem. 46:4164-4170.

Cantwell, M. and T.V. Suslow. 2010. Snap beans: Recommendations for maintaining postharvest quality. Postharvest Technology Research Information Center, University of California. 14 July 2010. <http://postharvest.ucdavis.edu/ Produce/ProduceFacts/Veg/snapbeans.shtml $>$.

CIAT. (2001). Centro Internacional de Agricultura Tropical. Common bean: The nearly perfect food. Cali, Columbia. 14 July 2010. <http:// cgiarfinanceinfo.org/ciatinfocus/beans.htm>.

Costa, M.A.C., J.K. Brecht, S.A. Sargent, and D.J. Huber. 1994. Tolerance of snap beans to elevated CO2 levels. Proc. Fla. State Hort. Soc. 107:271-273.

EPA-ERT (Environmental Protection Agency). E.R.T. 1994. Standard operating oProcedure 2030: Chlorophylls determination. 14 July 2010. <http://ert.org/products/2030.PDF>.

Favell, D.J. 1998. A comparison of the vitamin C content of fresh and frozen vegetables. Food Chem. 62:59-64.

Ferreira, M.E., A. de Varennes, J. P. de MeloAbreu, and M.I. Vieira. 2006. Predicting pod quality of green beans for processing. Sci. Hort. 109:207-211.

Fonseca, J.M. and R.A. Cinco. 2006. Evaluation of commercial alternatives to reduce postharvest pitting of organically grown zucchini and cucumber. Acta Hort. 712:291-297.

Francis, F.J. 1980. Color quality evaluation of horticultural crops. HortScience 15:58-59.

Freeman, D.W. and W.A. Sistrunk. 1978. Effects of post-harvest storage on quality of canned snap beans. J. Food Sci. 43:211-214.

Gorini, F., G. Borinelli, and T. Maggiore. 1974. Studies on precooling and storage of some varieties of snap beans. Acta Hort. 38:507530.

Gould, W.A., F.A. Krantz, and J. Mavis. 1951. Quality evaluation of fresh, frozen, and canned yellow sweet corn. Food Technol. 5:175-179.

Groesche, E.C., A.I. Nelson, and M.P. Steinber. 1966. Changes in color and other characteristics of green beans stored in controlled refrigerated atmospheres. J. Food Sci. 31:488-496.

Hardenburg, R.E., A.E. Watada, and C.Y. Wang. 1986. The commercial storage of fruits, vegetables, and florist and nursery stocks. USDA, Washington, DC.

Henderson, J. and R.W. Buescher. 1977. Regulation of broken-end discoloration in snap beans. HortScience 12:234.

Howard, L.A., A.D. Wong, A.K. Perry, and B.P. Klein. 1999. Beta-carotene and ascorbic acid retention in fresh and processed vegetables. J. Food Sci. 64:929-936.

Hruschka, H.W. 1977. Postharvest weight loss and shrivel in five fruits and vegetables. Agricultural Research Service, U.S. Department of Agriculture. Marketing Research Report No. 1059.

Kahn, B.A. and W.G. McGlynn. 2009. Relating objective and subjective ratings of snap bean pod color to likelihood of purchase. HortScience 44:737-741.

Kays, S.J. 1991. Postharvest physiology of perishable plant products. Van Nostrand Reinhold, New York, NY.

Kays, S.J. and R.E. Paull. 2004. Postharvest biology. Exon Press, Athens, GA.

Lee, S.K. and A.A. Kader. 2000. Preharvest and postharvest factors influencing vitamin $\mathrm{C}$ content of horticultural crops. Postharvest Biol. Technol. 20:207-220.

Martinez, C., G. Ros, M.J. Periago, G. Lopez, J. Ortuno, and F. Rincon. 1995. Physicochemical and sensory quality criteria of green beans (Phaseolus-vulgaris, L). LWT-Food Sci. Technol. 28:515-520.

Mayland, H.F. and L.L. Dean. 1971. Chlorophylls content of persistent-green and normal snap bean pods (Paseolus-vulgaris L). J. Amer. Soc. Hort. Sci. 96:362-365.

Miller, E.V. and A.S. Heilman. 1952. Ascorbic acid and physiological breakdown in the fruits of the pineapple (Ananas-Comosus L Merr). Science 116:505-506.

Monreal, M., B. De Ancos, and M.P. Cano. 1999. Influence of critical storage temperatures on degradative pathways of pigments in green beans (Phaseolus vulgaris cvs. Perona and Boby). J. Agr. Food Chem. 47:19-24.

Nunes, M.C.N. (ed.). 2008a. Color atlas of postharvest quality of fruits and vegetables. WileyBlackwell Publishing, Ames, IA.

Nunes, M.C.N. 2008b. Impact of environmental conditions on fruit and vegetable quality. Stewart Postharv. Rev. 4:1-14.

Nunes, M.C.N., J.K. Brecht, A.M.M.B. Morais, and S.A. Sargent. 1998. Controlling temperature and water loss to maintain ascorbic acid levels in strawberries during postharvest handling. J. Food Sci. 63:1033-1036.

Nunes, M.C.N. and J.P. Emond. 2002. Storage temperature, p. 209-228. In: Bartz, J.A. and J.K. Brecht (eds.). Postharvest physiology and pathology of vegetables. 2nd Ed. revised and expanded. Marcel Dekker, New York, NY.

Nunes, M.C.N., J.P. Emond, and J.K. Brecht. 2001 Temperature abuse during ground and in-flight handling operations affects quality of snap beans. HortScience 36:510 [abstr.]

Nunes, M.C.N., J.P. Emond, and J.K. Brecht. 2004. Quality curves for highbush blueberries as a function of the storage temperature. Small Fruits Review 3:423-440.

Nunes, M.C.N., J.P. Emond, J.K. Brecht, S. Dea, and E. Proulx. 2007. Quality curves for mango as a function of the storage temperature. J. Food Qual. 30:104-120.

Orzolek, M.D., G.L. Greaser, and J.K. Harper. 2000. Agricultural alternatives: Snap bean production (UA289) Penn State Cooperative Extension. Mar. 2010. <http://pubs.cas.psu.edu/ FreePubs/pdfs/ua289.pdf $>$.

Proulx, E., M.C.N. Nunes, J.-P. Emond, and J.K. Brecht. 2005. Quality attributes limiting papaya postharvest life at chilling and non-chilling temperatures. Proc. of the Florida State Horticultural Society 118:389-395.

Purvis, A.C. 1995. Genetic factors in the susceptibility of Cucumis sativus fruit to chilling injury. Acta Hort. 379:41-48.

Quintana, M.E.G. and R.E. Paull. 1993. Mechanical injury during postharvest handling of solo papaya fruit. J. Amer. Soc. Hort. Sci. 118:618622.

Reeve, R.M. and M.S. Brown. 1968. Histological development of green been pod as related to culinary texture. 2 . Structure and composition at edible maturity. J. Food Sci. 33:326-331. 
Robinson, J.E., K.M. Browne, and W.G. Burton. 1975. Storage characteristics of some vegetables and soft fruits. Ann. Appl. Biol. 81: 399-408.

SAS Institute Inc. 1982. SAS user's guide: Statistic. SAS Institute Inc., Cary, NC.

Sistrunk, W.A., A.R. Gonzalez, and K.J. Moore. 1989. Quality and preservation of vegetables. CRC Press, Boca Raton, FL.

Terada, M., Y. Watanabe, M. Kunitomo, and E. Hayashi. 1978. Differential rapid analysis of ascorbic-acid and ascorbic-acid 2-sulfate by dinitrophenylhydrazine method. Anal. Biochem. 84:604-608.
Trail, M.A., I.A. Wahem, and J.N. Bizri. 1992. Snap bean quality changed minimally when stored in low-density polyolefin film package. J. Food Sci. 57:977-979.

Watada, A.E. and L.L. Morris. 1966a. Effect of chilling and non-chilling temperatures on snap bean fruits. Proc. of the American Society for Horticultural Science 89:368-374.

Watada, A.E. and L.L. Morris. 1966b. Post-harvest behavior of snap bean cultivars. Proc. Amer. Soc. Hort. Sci. 89:375-380.

Will, R., B. McGlasson, D. Graham, and D. Joyce. 2007. Postharvest. An introduction to the physiology and handling of fruit, vegetables and ornamentals. 5th Ed. UNSW Press, Sydney, Australia.

Woodruff, J.G., E.K. Heaton, and C. Ellis. 1962. Freezing green snap beans. Ga. Agric. Exp. Stn. Bull, 90.

Wu, Y., A.K. Perry, and B.P. Klein. 1992. Vitamin$\mathrm{C}$ and beta-carotene in fresh and frozen green beans and broccoli in a simulated system. J. Food Qual. 15:87-96.

Zind, T. 1989. Fresh trends '90_-A profile of fresh produce consumers. Packer Focus 96:37-41.

Zong, R.J., M. Cantwell, L. Morris, and V. Rubatzky. 1992. Postharvest studies on four fruit-type Chinese vegetables. Acta Hort. 318:345-354. 